\title{
Primary production in forests and grasslands of China: contrasting environmental responses of light- and water-use efficiency models
}

\author{
H. Wang ${ }^{1,2}$, I. C. Prentice ${ }^{1,3}$, and J. $\mathbf{N i}^{2,4,5}$ \\ ${ }^{1}$ Department of Biological Sciences, Macquarie University, Sydney, Australia \\ ${ }^{2}$ Institute of Botany, Chinese Academy of Science, Beijing, China \\ ${ }^{3}$ Grantham Institute and Division of Ecology and Evolution, Imperial College, London, UK \\ ${ }^{4}$ Alfred Wegener Institute for Polar and Marine Research, Potsdam, Germany \\ ${ }^{5}$ State Key Laboratory of Environmental Geochemistry, Institute of Geochemistry, Chinese Academy of Science, Guiyang, \\ China \\ Correspondence to: H. Wang (han.wang@mq.edu.au)
}

Received: 16 March 2012 - Published in Biogeosciences Discuss.: 12 April 2012

Revised: 6 August 2012 - Accepted: 3 October 2012 - Published: 22 November 2012

\begin{abstract}
An extensive data set on net primary production (NPP) in China's forests is analysed with the help of two simple theoretically derived models based on the light use efficiency (LUE) and water use efficiency (WUE) concepts, respectively. The two models describe the data equally well, but their implied responses to $\left[\mathrm{CO}_{2}\right]$ and temperature differ substantially. These responses are illustrated by sensitivity tests in which $\left[\mathrm{CO}_{2}\right]$ is kept constant or doubled, temperatures are kept constant or increased by $3.5 \mathrm{~K}$, and precipitation is changed by $\pm 10 \%$. Precipitation changes elicit similar responses in both models. But NPP in South China, especially, is reduced by warming in the LUE model, whereas it is increased in the WUE model. The $\left[\mathrm{CO}_{2}\right]$ response of the WUE model is much larger than that of the LUE model. It is argued that the two models provide upper and lower bounds for this response, with the LUE model more realistic for forests. The differences between the two models illustrate some potential causes of the large differences (even in sign) in the global NPP response of different global vegetation models to temperature and $\left[\mathrm{CO}_{2}\right]$.
\end{abstract}

\section{Introduction}

Dynamic global vegetation models, either "offline" or coupled with climate models, have been used extensively to predict the response of global net primary production and the terrestrial carbon balance to scenarios of future climate and atmospheric carbon dioxide concentration $\left(\left[\mathrm{CO}_{2}\right]\right)$ and to quantify the feedbacks from climate change to $\left[\mathrm{CO}_{2}\right]$ (Cramer et al., 2001; Prentice et al., 2001; Friedlingstein et al., 2006; Sitch et al., 2008). But large uncertainties persist, due to the differences among the predictions of different models.

The Fourth Assessment Report (AR4) of the Intergovernmental Panel on Climate Change (IPCC) (Denman et al., 2007) re-analysed results from Friedlingstein et al. (2006), breaking down the models' aggregate global responses to environmental changes into components representing different processes. This analysis revealed large disagreements at a fundamental level. Although all models showed a positive response of global NPP to $\left[\mathrm{CO}_{2}\right]$ increase alone (" $\mathrm{CO}_{2}$ fertilization"), the magnitude differed by a factor of five between the smallest and the largest modelled response. The response of NPP to global warming (and other associated climate changes) was positive in some models but negative in others. All models showed a negative effect of climate change on the overall terrestrial carbon balance ("climatecarbon cycle feedback"), but the modelled responses differed by a factor of 7.5. Subsequent DGVM development, particularly the inclusion of an interactive terrestrial nitrogen cycle in several models (e.g. Sokolov et al., 2008; Thornton et al., 2009; Zaehle and Friend, 2010), has failed to reduce this uncertainty. Some models have even shown an increase in terrestrial carbon storage with global warming (Thornton et al., 2009; Sokolov et al., 2008), although this appears to 
be inconsistent with atmospheric constraints indicating that warming reduces terrestrial carbon storage and increases atmospheric $\left[\mathrm{CO}_{2}\right]$ (Friedlingstein and Prentice, 2010).

One possible approach to narrowing the uncertainties in DGVMs is to test simpler, stand-alone models for the component processes. We suggest that the important differences in the ways in which models represent processes might be reducible to a small set of contrasting assumptions. We focus here on the controls of primary production, the most fundamental of all terrestrial ecosystem processes. We exploit a large data set of forest NPP measurements spanning the range of forest types in China (Luo, 1996), supplemented by a smaller data set of grassland NPP measurements, to explore the predictions made by simple but theoretically derived models based on the concepts of water-use efficiency (WUE) and light-use efficiency (LUE) respectively. We find that the observations can be fitted by both types of model, while revealing important differences in their predictions for the responses of NPP to changes in $\left[\mathrm{CO}_{2}\right]$ and climate. Because of the relative simplicity of the models we can begin to analyse their differences, and suggest which aspects of the responses might need to be better characterized empirically.

\section{Materials and methods}

\subsection{Background}

Carbon dioxide assimilation through the stomata of vascular plants inevitably entails simultaneous loss of water to the atmosphere. The concept of WUE (the ratio of carbon assimilated to water lost) quantifies this trade-off. WUE has attracted increased interest recently, with the surge in popularity of the eddy covariance technique to quantify carbon gain and water loss at the ecosystem level (Baldocchi, 1994; Kuglitsch et al., 2008; Jassal et al., 2009). The idea of using water use (via WUE) to predict assimilation has been used for modelling crop growth (GLAM, Challinor et al., 2004) and large-scale gross primary production, GPP (Beer et al., 2007).

The concept of LUE (the ratio of carbon assimilation to absorbed photosynthetically active radiation, PAR) also emerged from studies of crop growth (Monteith and Moss, 1977). LUE gained popularity as a way to calculate GPP from incident PAR and remotely sensed measurements of the fraction of absorbed PAR green plants (fAPAR) (e.g. Prince and Goward, 1995; Running et al., 2004). The LUE concept is used in the Lund-Potsdam-Jena (LPJ) DGVM (Sitch et al., 2003) and its derivatives. LPJ relies on a theoretical analysis (Haxeltine and Prentice, 1996a) to predict LUE as a function of environmental controls, based on a simplified version of the Farquhar et al. (1980) model of photosynthesis. An important assumption of this analysis is that photosynthetic capacity acclimates to environmental conditions so as to maxi- mize daily net photosynthesis at the leaf level (Haxeltine and Prentice, 1996b; Dewar, 1996).

In applying the WUE and LUE concepts, we proceed in two steps (Table 1):

- First we fit "Level 0" or empirical models, in which simple proportional relationships between measured annual forest NPP and either an estimate of annual evapotranspiration (WUE), or an estimate of annual PAR absorption (LUE), are fitted statistically. Annual evapotranspiration for the Level 0 WUE model is derived from annual precipitation and annual equilibrium evapotranspiration (a measure related closely to potential evapotranspiration) using a well-established relationship in hydrology, derived from the so-called Budyko framework in which evapotranspiration is taken to vary smoothly between two end-states representing control by water availability (in dry climates) and control by energy availability (in wet climates). Annual PAR absorption for the LUE model is obtained as the product of annual incident PAR and a satellite-derived estimate of annual fAPAR, the fraction of incident PAR that is absorbed by green plants.

- Second, in order to perform sensitivity experiments in which environmental factors including $\mathrm{CO}_{2}$ concentration are varied, we develop "Level 1" or semi-empirical models. These are based on explicit theoretical derivations of the WUE and LUE concepts. The Level 1 models are also statistically fitted with the same forest NPP data set, but the predictor variables (annual evapotranspiration and annual PAR absorption, respectively) are modified to take into account additional expected effects of environmental variation on WUE and LUE. Specifically, the Level 1 WUE model takes into account the effect of vapour pressure deficit on stomatal conductance. We estimate this effect indirectly, using a previously published empirical relationship between leaf $\delta^{13} \mathrm{C}$ and a climatic moisture index. The Level 1 LUE model takes into account the known dependence of the photosynthetic $\mathrm{CO}_{2}$ compensation point on temperature, and an empirical relationship between the climatic moisture index and fAPAR.

The derivations of both of the Level 1 models rely on two simplifying assumptions. (1) We assume that light, water and $\left[\mathrm{CO}_{2}\right]$ are the primary controls on GPP; and therefore, that soil nutrient availability is a secondary consideration (contrary to some interpretations, e.g. Huston and Wolverton, 2009). (2) Although not pre-assigned any particular fraction, NPP is implicitly assumed to be approximately a constant fraction of GPP - that is, annual autotrophic respiration is assumed to be a fixed fraction of GPP or, equivalently, carbon use efficiency is taken to be constant across different environments and climates (Waring et al., 1998). This second assumption appears to be contrary to the analysis of Piao 
Table 1. Fitted linear regression models with dependent variables, explanatory variables, correlation coefficients $(r)$ and regression slopes (without intercept).

\begin{tabular}{lllll}
\hline Models & $\begin{array}{l}\text { Dependent } \\
\text { variables }\end{array}$ & $\begin{array}{l}\text { Explanatory } \\
\text { variables }\end{array}$ & $r$ & Slope \\
\hline Level 0 & forest NPP & $E_{\mathrm{a}}$ & 0.6544 & 1.0712 \\
models & forest NPP & $\mathrm{IPAR}_{0} \cdot \mathrm{fAPAR}$ & 0.6638 & 0.2633 \\
Level 1 & forest NPP & $E_{\mathrm{a}}\left(c_{\mathrm{i}} / c_{\mathrm{a}}\right)^{2} /\left(1-c_{\mathrm{i}} / c_{\mathrm{a}}\right)$ & 0.6485 & 0.2589 \\
WUE & Beer et al. GPP & $E_{\mathrm{a}}\left(c_{\mathrm{i}} / c_{\mathrm{a}}\right)^{2} /\left(1-c_{\mathrm{i}} / c_{\mathrm{a}}\right)$ & 0.8890 & 0.4513 \\
model & Grassland ANPP & $E_{\mathrm{a}}\left(c_{\mathrm{i}} / c_{\mathrm{a}}\right)^{2} /\left(1-c_{\mathrm{i}} / c_{\mathrm{a}}\right)$ & 0.3363 & 0.1781 \\
Level 1 & Forest NPP & $\operatorname{IPAR}_{0} \cdot \operatorname{fAPAR}\left(c_{\mathrm{i}}-\Gamma^{*}\right) /\left(c_{\mathrm{i}}+2 \Gamma^{*}\right)$ & 0.6268 & 0.3516 \\
LUE & Beer et al. GPP & $\operatorname{IPAR}_{0} \cdot \operatorname{fAPAR}\left(c_{\mathrm{i}}-\Gamma^{*}\right) /\left(c_{\mathrm{i}}+2 \Gamma^{*}\right)$ & 0.8843 & 0.6168 \\
model & Grassland ANPP & $\operatorname{IPAR}_{0} \cdot \operatorname{fAPAR}\left(c_{\mathrm{i}}-\Gamma^{*}\right) /\left(c_{\mathrm{i}}+2 \Gamma^{*}\right)$ & 0.3055 & 0.1442 \\
\hline
\end{tabular}

et al. (2010); however, subsequent re-analysis of the available co-located NPP and GPP data has revealed that the ratio of autotrophic respiration to GPP becomes independent of mean annual temperature when the distinction between managed and old-growth forests is taken into account (S. Piao and P. Ciais, personal communication, 2011). The NPP data we use are from managed forests of various ages. Both assumptions are re-examined later on.

Since the NPP data we exploit here refer to mean annual productivity, the entire approach is for "equilibrium" conditions. All the formulas involved in the estimation of water use and light use are intended to be valid at an annual scale, not for any shorter period.

\subsection{Data}

\subsubsection{NPP data}

1238 plot-based records of forest total (above- plus belowground) NPP were obtained from a dataset constructed by Luo (1996) and Ni (2003), which in turn was based on the Chinese literature from the 1970 s to 1990 s and the continuous forest-inventory plots of the State Forestry Administration during the period of 1989 to 1993 . Most of the plots are managed forest, while only $17 \%$ plots are "old-growth" forest (>100 yr old). The data in Luo (1996) are provided in tonnes $(\mathrm{Mg})$ dry matter ha $\mathrm{h}^{-1} \mathrm{a}^{-1}$. We converted the data to $\mathrm{g} \mathrm{C} \mathrm{m}^{-2} \dot{\mathrm{a}}^{-1}$, using a factor of 0.5 to convert dry matter to carbon content.

We also used 135 records of above-ground NPP (ANPP) compiled by $\mathrm{Ni}$ (2004) from field measurements of managed semi-natural grasslands in northern China. All the grasslands are grazed, but heavily disturbed sites were avoided. $\mathrm{Ni}$ (2004) derived total NPP from these sites, but the results are strongly dependent on the estimates used for below-ground carbon allocation. This is especially true for the driest and coldest sites where the bulk of the production occurs below ground. We have used only the above-ground NPP measurements in this study, as they are closer to the primary observa- tions. We then examine the implications of our findings for ANPP / NPP ratios.

We have also used the globally extrapolated GPP data of Beer et al. (2010) at $0.5^{\circ}$ resolution as a way to obtain an independent estimate of the WUE and LUE of GPP at the grid cells where we have NPP measurements. By comparing results obtained from Chinese forest NPP measurements with results obtained for the global GPP data set, we are able to get a rough estimate of the actual ratio of NPP to GPP for forests in the region. Even though the dataset of Beer et al. (2010) is a modelled product, this dataset can still be used as an independent check of our models, since it is based on observations (eddy-covariance flux measurements) that are independent of our NPP data.

\subsubsection{Environmental data}

The bioclimatic variables used in all of the Level 0 and Level 1 models were calculated from spatially interpolated (gridded) climatological data. Mean monthly values of temperature, precipitation, and percentage of possible sunshine hours were derived from 1814 meteorological stations across China (740 stations have observations from 1971-2000, the rest from 1981-1990: China Meteorological Administration, unpublished data). These data were interpolated at $0.1^{\circ}$ grid resolution for mapping, and to the specific locations and elevations of the forest NPP plots, using three-dimensional smoothing splines (ANUSPLIN version 4.36: Hancock and Hutchinson, 2006). Bioclimatic variables were then calculated as in Prentice et al. (1993, 2011): the daily mean temperature during the growing season (the period with dailyinterpolated temperatures $\left.>0{ }^{\circ} \mathrm{C}\right)\left(\mathrm{mGDD}_{0},{ }^{\circ} \mathrm{C}\right)$, the total annual incident photosynthetically active radiation during the growing season (IPAR ${ }_{0}, \mathrm{~mol} \mathrm{~m}^{-2} \mathrm{a}^{-1}$ ), annual equilibrium evapotranspiration $\left(E_{\mathrm{q}}, \mathrm{mm} \mathrm{a}^{-1}\right)$, and the climatic moisture index $\left(\mathrm{MI}=\mathrm{MAP} / \mathrm{E}_{\mathrm{q}}\right.$ where MAP is mean annual precipitation, $\left.\mathrm{mm} \mathrm{a}^{-1}\right)$.

Equilibrium evapotranspiration is defined as the stable rate of evapotranspiration that is approached when air passes over a homogeneous, well-watered surface under constant 
environmental conditions. Although these conditions are hypothetical, $E_{\mathrm{q}}$ is a well understood physical quantity whose value depends only on temperature and net radiation according to the expression $\lambda E_{\mathrm{q}}=R_{\mathrm{n}}[s /(s+\gamma)]$ where $\lambda$ is the latent heat of vaporization of water (a weak function of temperature), $R_{\mathrm{n}}$ is net radiation, $s$ is the slope of the Clausius-Clapeyron relationship between the saturated vapour pressure of water and temperature (this slope itself increases with temperature), and $\gamma$ is the psychrometer constant. $E_{\mathrm{q}}$ forms the basis for the widely used Priestley-Taylor equation for potential evapotranspiration, $E_{\mathrm{p}}=1.26 E_{\mathrm{q}}$. Based on the Budyko framework, the equation $E_{\mathrm{a}}=E_{\mathrm{p}}\left[1+\mathrm{MI}-\left(1+\mathrm{MI}^{w}\right)^{1 / w}\right]$ (Zhang et al., 2004), where $w$ is a single empirical parameter with a limited range of values, makes it possible to estimate annual actual evapotranspiration $\left(E_{\mathrm{a}}, \mathrm{mm} \mathrm{a}^{-1}\right)$ from $\mathrm{MI}$ and $E_{\mathrm{q}}$. For simplicity, we set $w$ to a single generic the value of 3 , appropriate to forest, and $E_{\mathrm{p}}=E_{\mathrm{q}}$.

To test the robustness of this method to calculate $E_{\mathrm{a}}$, we compared its results with an alternative, more explicitly process-based method based on soil-moisture accounting, as described by Prentice et al. (1993). This method requires soil water-holding capacities to be assigned to grid cells: in this we followed Wang et al. (2011). In the soil-moisture accounting algorithm, daily $E_{\mathrm{a}}$ is computed using an analytical expression for the integral over the 24-h cycle of the lesser of two quantities: a demand function, which is $E_{\mathrm{q}}$, and a supply function. The supply function takes a maximum value of $1 \mathrm{~mm} \mathrm{~h}^{-1}$ which is diminished in proportion to the fractional volumetric soil water content, in order to mimic the observed reduction in transpiration rate as soils dry out. The soil is treated as a single water store to which precipitation is added and from which evapotranspiration is removed. If the store is full, the excess water runs off. The annual cycle is iterated until a stable seasonal cycle of evapotranspiration is reached. This algorithm yielded values of $E_{\mathrm{a}}$ that were larger by a factor 1.17 but with a very high correlation $(r=0.98)$ to the estimates made with the Zhang equation.

The variables $\mathrm{mGDD}_{0}, \mathrm{IPAR}_{0}, E_{\mathrm{q}}$, and $\mathrm{MI}$ and $E_{\mathrm{a}}$ estimated from the Zhang equation, are mapped in Fig. 1. The contents of three soil nutrient elements phosphorus, potassium and nitrogen at the forest NPP observation plots were obtained from the digitized 1:1 million soil map of China (Shi et al., 2004).

\subsection{Models}

\subsubsection{The simple (Level 0) WUE model}

Our Level 0 WUE model assumes simple proportionality between NPP and $E_{\mathrm{a}}$. We fitted this model to the forest NPP data by ordinary least-squares linear regression of NPP (observations) against $E_{\mathrm{a}}$ (from the Zhang equation), with the intercept fixed to zero (Table 1).

\subsubsection{Theoretical derivation of a (Level 1) WUE model}

Due to the resistance of stomata to the inward diffusion of $\mathrm{CO}_{2}$ and the photosynthetic drawdown of $\mathrm{CO}_{2}$ in the leaves, $c_{\mathrm{i}}$ in illuminated leaves is always less than $c_{\mathrm{a}}$. From the diffusion equation, the relationship between net photosynthesis and the $\mathrm{CO}_{2}$ concentration gradient across the leaf epidermis is:

$A=g_{\mathrm{s}} c_{\mathrm{a}}\left(1-c_{\mathrm{i}} / c_{\mathrm{a}}\right)$

where $A$ is GPP and $g_{\mathrm{s}}$ is stomatal conductance to $\mathrm{CO}_{2}$ (usually expressed in mol $\mathrm{C} \mathrm{m}^{-2} \mathrm{~s}^{-1}$ ). At the whole-ecosystem level as considered here, $g_{\mathrm{s}}$ is a bulk conductance, which depends on foliage cover as well as on the average leaf-level stomatal conductance.

The ratio of internal $\mathrm{CO}_{2}$ concentration $\left(c_{\mathrm{i}}, \mu \mathrm{mol} \mathrm{mol}{ }^{-1}\right.$ or ppm) to ambient $\mathrm{CO}_{2}$ concentration ( $c_{\mathrm{a}}$, in the same units) is an index of the regulation of stomatal conductance. We estimated effective growing-season values of $c_{\mathrm{i}} / c_{\mathrm{a}}$ as follows:

$c_{\mathrm{i}} / c_{\mathrm{a}}=0.426+0.417 \mathrm{MI}$.

This expression combines the standard approximation for $\delta^{13} \mathrm{C}_{\text {leaf }}$ (Farquhar et al., 1982, 1989) with an empirical regression equation for $\delta^{13} \mathrm{C}_{\text {leaf }}$ as a function of $\mathrm{MI}$ for $\mathrm{C}_{3}$ plants, based on field measurements ranging from dense forests to desert (MI from 0.17 to 0.96 ) along the North East China Transect (Prentice et al., 2011). Since stomatal conductance is regulated in a way that maintains $c_{\mathrm{i}} / c_{\mathrm{a}}$ typically around 0.7 to 0.9 in $\mathrm{C}_{3}$ plants under conditions of moderate vapour pressure deficit $(D)$ and adequate soil moisture (Wong et al., 1979), we assumed that $c_{\mathrm{i}} / c_{\mathrm{a}}$ does not increase beyond a maximum value of 0.843 for $\mathrm{MI} \geq 1$. Estimated values of $c_{\mathrm{i}} / c_{\mathrm{a}}$ are mapped in Fig. 1 .

Diffusion through the stomata also controls plant water loss according to:

$E=1.6 g_{\mathrm{s}} D$

where $E$ is transpiration and $D$ is the (dimensionless) vapour pressure deficit at the leaf surface. Here again $g_{s}$ is a bulk conductance. For simplicity we assume that evaporation from bare ground and interception from leaves add up to an approximately constant fractional loss of water to the plants, with evaporation from bare ground more important in sparsely vegetated environments and interception more important in forests. We thus derive a WUE model from Eqs. (1) and (3):

$A=0.63 q\left(c_{\mathrm{a}} / D\right)\left(1-c_{i} / c_{\mathrm{a}}\right) E_{\mathrm{a}}$

where $E_{\mathrm{a}}$ is actual evapotranspiration (including bare ground evaporation and interception), and $q(\leq 1)$ is the fraction of $E_{\text {a }}$ that is transpired. 

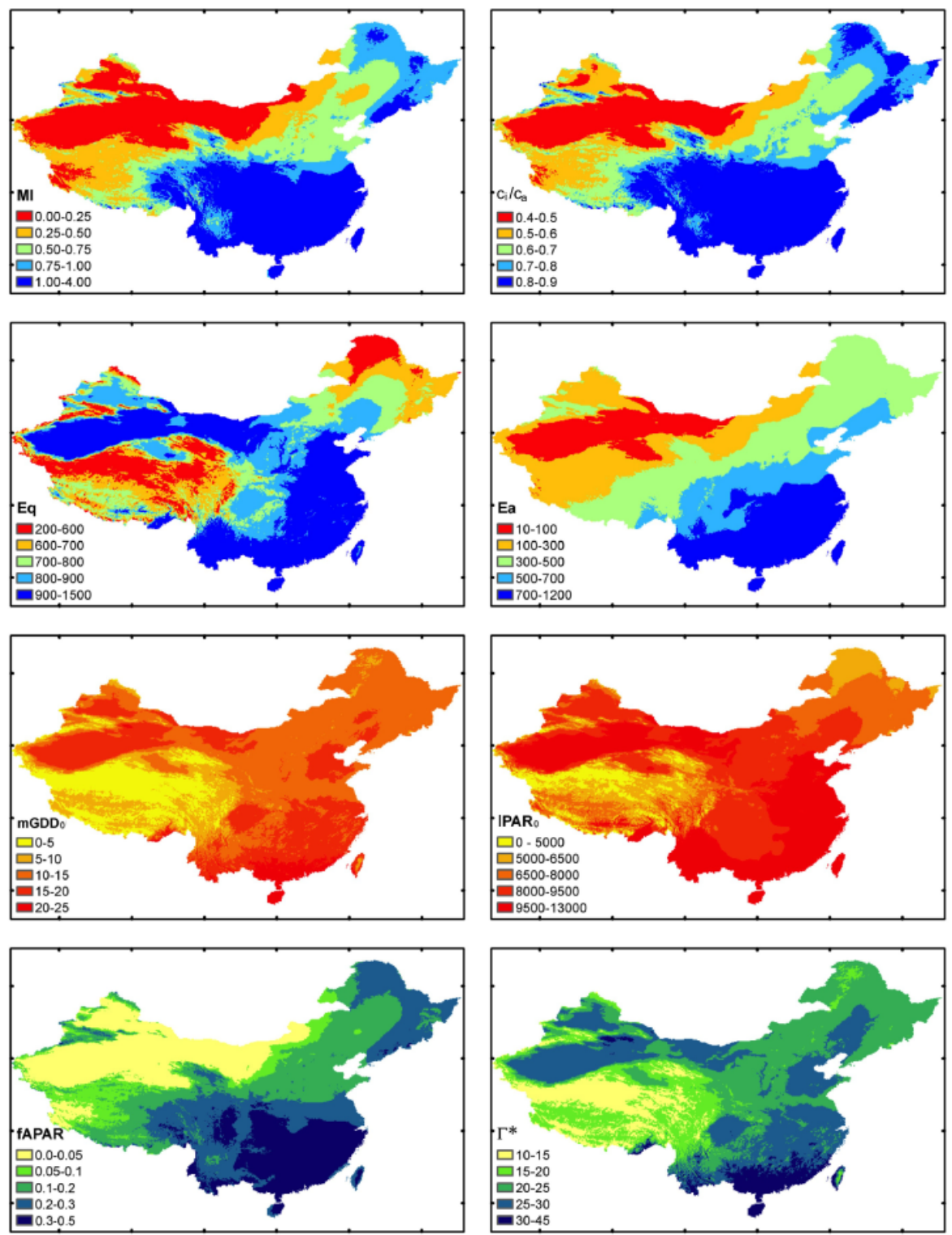

Fig. 1. The distribution pattern of eight environmental or ecophysiological variables: moisture index (MI), $c_{\mathrm{i}} / c_{\mathrm{a}}$ ratio, equilibrium evapotranspiration $\left(E_{\mathrm{q}}: \mathrm{mm} \mathrm{a}^{-1}\right)$, actual evapotranspiration $\left(E_{\mathrm{a}}: \mathrm{mm} \mathrm{a}^{-1}\right)$, mean temperature of the period above $0^{\circ} \mathrm{C}\left(\mathrm{mGDD}_{0}:{ }^{\circ} \mathrm{C}\right)$, accumulated photosynthetic active radiation during the period above $0{ }^{\circ} \mathrm{C}\left(\mathrm{IPAR}_{0}: \mathrm{mol} \mathrm{m}^{-2} \mathrm{a}^{-1}\right)$, fraction of absorbed photosynthetic active radiation (fAPAR), $\mathrm{CO}_{2}$ compensation point ( $\left.\Gamma^{*}: \mathrm{ppm}\right)$.

The effective, growing-season value of $D$ is unknown and not easily calculated from meteorological measurements. Many models require $D$ to be specified as an external variable in a similar way to temperature or precipitation. However, $D$ is not really independent of ecosystem properties; it is controlled by evapotranspiration and the dynamics of the planetary boundary layer, which in turn are determined by energy exchanges at the land surface as well as by conditions in the free troposphere (Raupach, 1995). Furthermore, stomatal optimization theory (Medlyn et al., 2011) implies a functional relationship between $D$ and $c_{\mathrm{i}} / c_{\mathrm{a}}$ :

$$
D=\xi^{2}\left(1-c_{\mathrm{i}} / c_{\mathrm{a}}\right)^{2} /\left(c_{\mathrm{i}} / c_{\mathrm{a}}\right)^{2}
$$

where $\xi$ is a parameter. There is some evidence that $\xi$ varies among species (Medlyn et al., 2011) and with leaf or soil water potential (Manzoni et al., 2011), but based on an analysis of available data from drying experiments, the response of $c_{\mathrm{i}} / c_{\mathrm{a}}$ to soil moisture appear to be relatively slight compared with its response to $D$ (Zhou et al., 2012). Accordingly, we do not consider variation in $\xi$ when estimating $D$. This simplification can be justified on two further grounds. First, 
because of the dependence of atmospheric water vapour content on transpiration, soil moisture index and $D$ (as the two controls of $c_{\mathrm{i}} / c_{\mathrm{a}}$ ) must themselves be mutually correlated, and therefore it is reasonable to expect a correlation between long-term values of $c_{\mathrm{i}} / c_{\mathrm{a}}$ and $D$. Second, and most importantly for our analysis, the estimates of $c_{\mathrm{i}} / c_{\mathrm{a}}$ from Eq. (2) implicitly include variation in $\xi$ with species and soil moisture to the extent this occurs. This is because they are based on observed ${ }^{13} \mathrm{C}$ discrimination by plants growing in their natural environment.

Substituting Eq. (5) into Eq. (4), we then obtain:

$$
A=0.63 q \xi^{-2} c_{\mathrm{a}} E_{\mathrm{a}}\left(c_{\mathrm{i}} / c_{\mathrm{a}}\right)^{2} /\left(1-c_{\mathrm{i}} / c_{\mathrm{a}}\right)
$$

Eq. (6) is our Level 1 WUE model, which could be fully expressed as:

$$
\begin{aligned}
A= & 0.63 q \xi^{-2} c_{\mathrm{a}} E_{\mathrm{p}}\left[1+\mathrm{MI}-\left(1+\mathrm{MI}^{w}\right)^{1 / w}\right] \\
& (0.426+0.417 \mathrm{MI})^{2} /(0.574-0.417 \mathrm{MI})
\end{aligned}
$$

by substituting $E_{\mathrm{a}}$ with the Zhang equation and $c_{\mathrm{i}} / c_{\mathrm{a}}$ with Eq. (2).

We fitted this model by ordinary least-squares linear regression of forest NPP data against the product $E_{\mathrm{a}}\left(c_{\mathrm{i}} / c_{\mathrm{a}}\right)^{2} /\left(1-c_{\mathrm{i}} / c_{\mathrm{a}}\right)$ with the intercept fixed to zero (Table 1).

\subsubsection{The simple (Level 0) LUE model}

Our Level 0 WUE model assumes simple proportionality between NPP and the product of incident PAR and annual fAPAR. We fitted this model to the forest NPP data by ordinary least-squares linear regression of NPP (observations) against the product $\mathrm{IPAR}_{0} \times$ fAPAR, with the intercept fixed to zero. To estimate annual fAPAR, we used monthly fAPAR data on a $0.5^{\circ}$ grid from the SeaWiFS satellite product (Gobron et al., 2006). Annual fAPAR is the ratio of total annual absorbed PAR to total annual incident PAR, and is therefore properly calculated as a weighted average of monthly values (weighted by each month's total incident PAR) (Fig. 1).

\subsubsection{Theoretical derivation of a (Level 1) LUE model}

We start from the assumption that the photosynthetic capacity of leaves at any level in the canopy acclimates spatially and temporally during the course of the growing season to the prevailing daytime incident PAR, so as to be neither in excess (which would entail additional, non-productive maintenance respiration) nor less than required for full exploitation of the available PAR (Haxeltine and Prentice, 1996a; Dewar, 1996). This assumption implies co-limitation of photosynthesis by carboxylation and electron transport under typical daytime conditions. It leads to the simplification that effects of environmental changes (water availability, temperature, $c_{\mathrm{a}}$ ) can be expressed through a simplified equation for electron-transport limited photosynthesis:

$A=\mathrm{fAPAR} \phi_{\mathrm{o}} \operatorname{IPAR}_{0}\left(c_{\mathrm{i}}-\Gamma^{*}\right) /\left(c_{\mathrm{i}}+2 \Gamma^{*}\right)$ where $\phi_{\mathrm{o}}$ is the intrinsic quantum efficiency of photosynthesis and $\Gamma^{*}$ is the $\mathrm{CO}_{2}$ compensation point. It is implicit that not only the Rubisco capacity $\left(V_{\mathrm{cmax}}\right)$ but also the maximum capacity for electron transport $\left(J_{\max }\right)$ acclimates to PAR, so that $A$ never approaches light saturation due to $J_{\max }$ limitation under typical daytime conditions. The relative conservatism of the ratio $J_{\max } / V_{\max }$ in wild plants (Wullschleger, 1993) supports this.

Equation (7) is our Level 1 LUE model. But although we have data on present-day fAPAR, a model is required to predict changes in fAPAR with changes in environment. Annual fAPAR is a remotely sensed quantity proportional to the green foliage projective cover (FPC). It is related to leaf area index (LAI) through Beer's law such that fAPAR is approximately proportional to LAI at low values of LAI $(<1)$, approaching 1 at high values of LAI. It has long been known (e.g. Specht, 1972) that water availability is the dominant control of evergreen (or growing-season) FPC, and more recent analyses (e.g. Nemani and Running, 1989, Kergoat, 1998) have shown that large-scale patterns of growingseason LAI are close to equilibrium with water supply. Based on this knowledge, we fitted a country-wide empirical relationship for fAPAR as a function of MI:

$\mathrm{fAPAR}=0.53\{1-\exp [-0.7(\mathrm{MI}-0.15)]\}$

using non-linear regression of the gridded SeaWiFS annual fAPAR data against MI. Equation (8) then allowed us to estimate fAPAR from MI.

The $\mathrm{CO}_{2}$ compensation point $\Gamma^{*}$ (ppm) depends strongly on temperature. Bernacchi et al. (2003) fitted the Arrhenius equation to measurements in vivo of $\Gamma^{*}$ at different temperatures. This relationship can be re-expressed to a close approximation, for the relevant range of temperatures, as an ordinary exponential function:

$\Gamma^{*}=\Gamma_{25}^{*} \exp (0.0512 \Delta T)$

where $\Delta T$ is the difference between the measurement temperature in ${ }^{\circ} \mathrm{C}\left(T_{\mathrm{C}}\right)$ and $25^{\circ} \mathrm{C}$. We substituted the mean growing-season temperature $\left(\mathrm{mGDD}_{0}\right)$ for $T_{\mathrm{C}}$ to estimate effective growing-season values of $\Gamma^{*}$. These are mapped in Fig. 1 .

Therefore, our Level 1 LUE model could be fully expressed as:

$$
\begin{aligned}
A= & 0.53\{1-\exp [-0.7(\mathrm{MI}-0.15)]\} \phi_{\mathrm{o}} \mathrm{IPAR}_{0} \\
& \left\{0.426 c_{\mathrm{a}}+0.417 c_{\mathrm{a}} \mathrm{MI}-\Gamma_{25}^{*} \exp (0.0512 \Delta T)\right\} / \\
& \left\{0.426 c_{\mathrm{a}}+0.417 c_{\mathrm{a}} \mathrm{MI}+2 \Gamma_{25}^{*} \exp (0.0512 \Delta T)\right\}
\end{aligned}
$$

by substituting in Eq. (8) with $c_{\mathrm{i}} / c_{\mathrm{a}}$ from Eq. (2), fAPAR from Eq. (9) and $\Gamma^{*}$ from Eq. (10).

To fit the model, we performed a linear regression of the $\mathrm{NPP}$ data on the product fAPAR $\times \operatorname{IPAR}_{0}\left(c_{\mathrm{i}}-\Gamma^{*}\right) /\left(c_{\mathrm{i}}+\right.$ $\left.2 \Gamma^{*}\right)$ with $c_{\mathrm{i}} / c_{\mathrm{a}}$ estimated from Eq. (2), fAPAR from Eq. (8), $\Gamma^{*}$ from Eq. (9), and the intercept fixed to zero. 


\subsection{Additional tests}

To test for a possible dependence of NPP on soil nutrient availability, we categorized the soil $\mathrm{P}, \mathrm{K}$ and $\mathrm{N}$ concentrations for each forest NPP measurement site (identifying suitable breakpoints based on histograms of the values) and performed separate performed separate regressions of NPP on the light- and water-based predictors for the different categories. To test for a possible dependence of NPP on stand age, we also performed separate regressions for three stand age classes $(<50 \mathrm{yr}, 50-100 \mathrm{yr}$ and $>100 \mathrm{yr})$.

We also fitted the Level 1 WUE and LUE models to the GPP dataset of Beer et al. (2010) (Table 1). Using GPP data, the regression slope of the WUE model can be interpreted as an estimate of $0.63 q \xi^{-2} c_{\mathrm{a}}$ and the regression slope of the LUE model can be interpreted as an estimate of $\phi_{0}$. Furthermore, by comparing these slopes with those obtained from fitting the forest NPP data, we could obtained a rough estimation of the average ratio of NPP to GPP in the forest plots.

Grasslands occupy a large area of China and play a significant role in China's terrestrial carbon cycle. We tested the models' applicability to grasslands as well as forests. We fitted Level 1 WUE and LUE models to the grassland ANPP data of Ni (2004) and compared the results with those obtained with the forest NPP data (Table 1). If the true relationships of NPP to the predictors were similar in forests and grasslands, then we would expect the ratios of the slopes to indicate the fraction of grassland NPP allocated above ground. We therefore compared these ratios to the results of Hui and Jackson (2006), whose estimates of belowground NPP were based on 94 site-years of field biomass measurements at twelve grassland sites around the world.

\subsection{Sensitivity experiments}

Regional averages of temperature and precipitation projections under the A1B scenario for 2080 to 2099 from IPCC AR4 (Christensen et al., 2007) were used to suggest simple sensitivity experiments as follows. For all $0.1^{\circ}$ grid cells the mean temperature of each month was increased by $3.5 \mathrm{~K}$ and the mean precipitation of each month altered by $\pm 10 \%$. We considered changes of each single climatic factor, and both together, under recent $\left[\mathrm{CO}_{2}\right](366 \mathrm{ppm})$ and doubled $\left[\mathrm{CO}_{2}\right]$ $(732 \mathrm{ppm})$. For each projected climate and $\left[\mathrm{CO}_{2}\right]$ level, we mapped the changes from the baseline state, and also calculated the area-weighted average NPP across all grid cells.

\section{Results}

\subsection{Analysis of forest NPP data}

Both Level 0 models (WUE and LUE) yielded highly significant regressions, with closely similar correlation coefficients $(r=0.650$ for WUE model and 0.664 for LUE model) (Table 1).
The Level 1 WUE and LUE models also yielded highly significant regressions, and correlation coefficients similar to those from the Level 0 models $(r=0.649,0.627)$ (Table 1 , Fig. 2). That these correlations are slightly smaller than those obtained with the Level 0 models suggests that the theoretically derived models could be improved. This is not surprising as a number of additional assumptions were made in the derivations. But the differences are small.

When different soil nutrient classes were analysed separately using the Level 1 models, some statistically significant differences were found among the regression slopes (Table 2, Fig. 3). There is a significant difference between the WUE model slopes for low and high $\mathrm{P}$ concentration, but the magnitudes differ by only $7.6 \%$. The largest percentage difference in slopes $(20.8 \%)$ was between soils with low and high $\mathrm{K}$ concentration. The results generally indicate a greater slope for higher nutrient availability, except for the highest level of P in the LUE model, which breaks this trend. Low and high $\mathrm{N}$ classes showed no significant differences in slope.

There were small but significant differences in the regression slopes for the different age classes, with the $>100 \mathrm{yr}$ age class showing a slope reduced by $14 \%$ (Table 3, Fig. 3).

\subsection{Modelled responses of NPP to changes in climate and $\left[\mathrm{CO}_{2}\right]$}

Precipitation changes elicited similar responses in both models: increasing NPP with more precipitation, and decreasing NPP with less (Table 4, Fig. 4). Under recent $\left[\mathrm{CO}_{2}\right]$, the WUE model estimated an area-weighted average NPP of $369 \mathrm{~g} \mathrm{C} \mathrm{m}^{-2} \mathrm{a}^{-1}$ and the LUE model $393 \mathrm{~g} \mathrm{C} \mathrm{m}^{-2} \mathrm{a}^{-1}$. The modelled changes of NPP between baseline and $10 \%$ precipitation change were similar: $-40 \mathrm{~g} \mathrm{C} \mathrm{m}^{-2} \mathrm{a}^{-1}$ (WUE model) and $-37 \mathrm{~g} \mathrm{C} \mathrm{m}^{-2} \mathrm{a}^{-1}$ (LUE model) with less precipitation, and $+36 \mathrm{~g} \mathrm{C} \mathrm{m}^{-2} \mathrm{a}^{-1}$ (WUE model) and $+34 \mathrm{~g} \mathrm{C} \mathrm{m}^{-2} \mathrm{a}^{-1}$ (LUE model) with more precipitation. The responses of NPP to precipitation were in the same direction under doubled $\left[\mathrm{CO}_{2}\right]$. Both models also indicated a regional heterogeneity in the NPP response to precipitation change. Under recent $\left[\mathrm{CO}_{2}\right]$, both models showed larger absolute NPP changes in wet regions. But the WUE model indicated the highest sensitivity region at the transition between wet and dry regions, while the LUE model indicated the highest sensitivity in wet regions.

Warming was predicted to have a negative effect on areaweighted average NPP, with a change of -7 (WUE model) or $-22 \mathrm{~g} \mathrm{C} \mathrm{m}^{-2} \mathrm{a}^{-1}$ (LUE model). The regional patterns of response differed between the models. In the LUE model, warming reduced NPP over most of China, with the strongest effect in South China. Exceptions were for a large area in Tibetan Plateau, and a small area in the transition between the wet and dry regions. Reductions of more than $75 \mathrm{~g} \mathrm{C} \mathrm{m}^{-2} \mathrm{a}^{-1}$ were simulated (Fig. 4). In the WUE model, NPP generally increased by $>25 \mathrm{~g} \mathrm{C} \mathrm{m}^{-2} \mathrm{a}^{-1}$ in South China, with negative 
Table 2. Regression slopes of observed NPP against Level 1 WUE and LUE model predictors for different soil nutrient levels, and t-values for all pairwise comparisons among the levels (bold: $P<0.05$ or better).

\begin{tabular}{|c|c|c|c|c|c|}
\hline \multirow{2}{*}{$\begin{array}{l}\text { WUE model } \\
\mathrm{N} \text { concentration }\end{array}$} & \multirow[t]{2}{*}{ slope } & \multirow{2}{*}{$\begin{array}{r}\text { standard } \\
\text { error }\end{array}$} & \multirow{2}{*}{$\begin{array}{r}\text { sample } \\
\text { size }\end{array}$} & \multicolumn{2}{|c|}{ pairwise t-values } \\
\hline & & & & $<0.2$ & \\
\hline$<0.2$ & 0.2600 & 0.0037 & 775 & & \\
\hline$\geq 0.2$ & 0.2565 & 0.0053 & 463 & 0.5555 & \\
\hline P concentration & & & & $\leq 0.05$ & $\geq 0.15$ \\
\hline$\leq 0.05$ & 0.2555 & 0.0041 & 515 & & $\overline{2.0691}$ \\
\hline$\overline{0} .05-0.15$ & 0.2618 & 0.0049 & 579 & 0.9727 & 0.9728 \\
\hline$\geq 0.15$ & 0.2765 & 0.0124 & 144 & & \\
\hline K concentration & & & & $\leq 0.5$ & $\geq 4$ \\
\hline$\leq 0.5$ & 0.2503 & 0.0051 & 419 & & $2.7 \overline{688}$ \\
\hline $0.5-4$ & 0.2598 & 0.0039 & 779 & 1.4612 & 2.1652 \\
\hline$\geq 4$ & 0.2978 & 0.0151 & 40 & & \\
\hline LUE model & slope & standard error & sample size & pairsie & -values \\
\hline $\mathrm{N}$ concentration & & & & $<0.2$ & \\
\hline$<0.2$ & 0.3552 & 0.0030 & 775 & & \\
\hline$\geq 0.2$ & 0.3445 & 0.0039 & 463 & 1.3633 & \\
\hline P concentration & & & & $\leq 0.05$ & $\geq 0.15$ \\
\hline$\leq 0.05$ & 0.3520 & 0.0035 & 515 & & $\overline{2.8518}$ \\
\hline $0.05 \sim 0.15$ & 0.3563 & 0.0037 & 275 & 0.4909 & 3.3671 \\
\hline$\geq 0.15$ & 0.3173 & 0.0071 & 144 & & \\
\hline K concentration & & & & $\leq 0.5$ & $\geq 4$ \\
\hline$\leq 0.5$ & 0.3414 & 0.0042 & 419 & & $3.9 \overline{354}$ \\
\hline$\overline{0.5} \sim 4$ & 0.3502 & 0.0029 & 779 & 1.0973 & 3.8396 \\
\hline$\geq 4$ & 0.4312 & 0.0139 & 40 & & \\
\hline
\end{tabular}

Table 3. Regression slopes of observed NPP against Level 1 WUE and LUE model predictors for three stand age classes, and t-values for all pairwise comparisons among the three classes (bold: $P<0.05$ or better).

\begin{tabular}{lrrrrr}
\hline $\begin{array}{l}\text { WUE model } \\
\text { stand age }\end{array}$ & slope & $\begin{array}{r}\text { standard } \\
\text { error }\end{array}$ & $\begin{array}{r}\text { sample } \\
\text { size }\end{array}$ & \multicolumn{2}{r}{$\begin{array}{r}\text { pairwise t-values } \\
<50\end{array}$} \\
\hline$<50$ & 0.2639 & 0.0040 & 657 & & $\mathbf{4 . 3 5 6 5}$ \\
$50-100$ & 0.2654 & 0.0059 & 348 & 0.2146 & $\mathbf{3 . 9 0 9 2}$ \\
$>100$ & 0.2290 & 0.0072 & 233 & & \\
\hline LUE model & slope & standard error & sample size & pairwise t-values \\
\hline stand age & & & & $<50$ & $>100$ \\
$<50$ & 0.3674 & 0.0033 & 657 & & $\mathbf{5 . 7 7 9 1}$ \\
$50-100$ & 0.3456 & 0.0043 & 348 & 1.8151 & $\mathbf{3 . 9 3 1 4}$ \\
$>100$ & 0.3021 & 0.0055 & 233 & & \\
\hline
\end{tabular}

responses elsewhere, and no increase in the Tibetan Plateau region.

When warming and changes in precipitation were combined, both models indicated a similar tendency: the effect of precipitation change was stronger than that of warming in the north, but weaker in the south (Fig. 4). But the geographic response patterns were different. In the LUE model, warming and reduced precipitation together led to an overall NPP reduction. Higher NPP in the north was approximately balanced by lower NPP in the south. In the WUE model warming and increased precipitation enhanced overall NPP.

The area-weighted average NPP indicates a much larger $\left[\mathrm{CO}_{2}\right]$ response of the WUE model than the LUE model (Table 4), enhancing the positive effect of precipitation increase and warming in the south while counteracting the negative effect of precipitation decrease and warming in the north. In 
Table 4. Area-weighted average predicted NPP $\left(\mathrm{g} \mathrm{C} \mathrm{m}^{-2} \mathrm{a}^{-1}\right)$ in baseline climate scenarios under recent $\left[\mathrm{CO}_{2}\right]$ and relative changes of area-weighted average predicted $\left(\mathrm{g} \mathrm{C} \mathrm{m}^{-2} \mathrm{a}^{-1}\right)$ for six climate scenarios under recent and doubled $\left[\mathrm{CO}_{2}\right]$.

\begin{tabular}{lllll}
\hline & \multicolumn{2}{c}{ recent $\left[\mathrm{CO}_{2}\right]$} & \multicolumn{2}{c}{ doubled $\left[\mathrm{CO}_{2}\right]$} \\
& WUE model & LUE model & WUE model & LUE model \\
\hline Baseline & 369 & 393 & +370 & +50 \\
Temperature $+3.5 \mathrm{~K}$ & -7 & -22 & +357 & +33 \\
Precipitation $-10 \%$ & -40 & -37 & +290 & +10 \\
Precipitation $+10 \%$ & +36 & +34 & +442 & +87 \\
Temperature $+3.5 \mathrm{~K}$ & -48 & -59 & +273 & -8 \\
Precipitation $-10 \%$ & & & & +72 \\
Temperature $+3.5 \mathrm{~K}$ & +32 & +13 & +435 & + \\
Precipitation $+10 \%$ & & & & \\
\hline
\end{tabular}

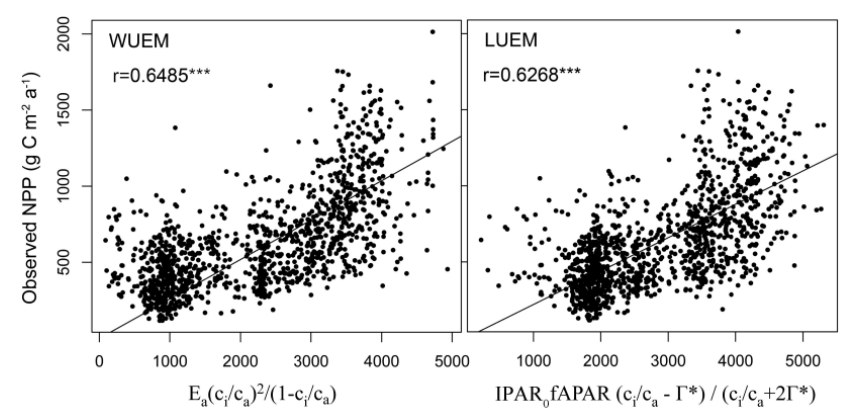

Fig. 2. Relationship between forest NPP and predictors in the Level 1 WUE and LUE models.

contrast, the $\left[\mathrm{CO}_{2}\right]$ response of the LUE model was not large enough to counteract the negative effect of warming and/or reduced precipitation in some regions (Fig. 5).

Desert, widely distributed in interior northwestern China, is the least productive ecosystem type with $<200 \mathrm{~g} \mathrm{C} \mathrm{m}^{-2} \mathrm{a}^{-1}$ WUE modelled NPP (Fig. 4). The two models showed completely different responses of desert NPP. The WUE model showed a positive response to both precipitation increase and doubled $\left[\mathrm{CO}_{2}\right]$ whereas the LUE model showed little change under any conditions.

\section{Discussion}

\subsection{Comparison with other analyses}

The Level 1 LUE and WUE models were additionally fitted to Beer et al.'s GPP data, yielding slopes of 0.617 and 0.451 (Table 1) with $r=0.88$ and 0.89 , respectively. The high correlations are to be expected, as climatic conditions play a leading role in the algorithms used by Beer et al. to extrapolate GPP. GPP values estimated in this way lack natural spatial variability due to variations in soil water capacity, nutrient availability, topography and land-use history. Such variability is not included either in Beer et al.'s procedure or in our models, while being inherent in field NPP measurements.

By comparing estimated regression slopes for the forest NPP data and for Beer et al.'s GPP data we can obtain some approximate information about the ratio of NPP to GPP. The comparison yields an implied NPP / GPP ratio of 0.57 in both the Level 1 models $(0.2589 / 0.4513$ in the WUE model and $0.3516 / 0.6168$ in the LUE model). The value of 0.57 can be compared e.g. with the generic value of 0.5 was suggested by Waring et al. (1998) and the mean value of 0.52 given by Zhang et al. (2009), with lower values in dense vegetation. (However, note that this is a pure model result, as the MODIS data retrievals contain no information about the NPP/GPP ratio). NPP / GPP ratios estimated by Zhang et al. (2009) for China ranged from 0.45 in the south to 0.7 in the interior. DeLucia et al. (2007) in a meta-analysis indicated NPP / GPP ratios ranging from 0.32 in old-growth boreal forests to 0.59 in temperate deciduous forests. Piao et al. (2010) indicated a range from about 0.3 to 0.5 , based on a global forest NPP and $\mathrm{CO}_{2}$ flux dataset compiled by Luyssaert et al. (2007).

When the forest sites were divided into age classes, forests $>100 \mathrm{yr}$ old (Fig. 3, Table 3) show lower regression slopes than the younger age classes. Lower slopes are consistent with lower GPP, and/or a reduced NPP/GPP ratio (e.g. Makela and Valentine, 2001), in old-growth forests. Either way, it is likely that somewhat higher overall values of LUE and WUE have been obtained from this managed forest data set than would be obtained for semi-natural forests with greater average age and biomass.

We compared our modelled values for forest WUE (defined as the ratio of predicted NPP to $E_{\mathrm{a}}$ ) with independent determinations for the main forest types (broad-leaved deciduous, broad-leaved evergreen, needle-leaved evergreen, mixed) by Beer et al. (2009) and Zhu et al. (2011). Zhu et al. (2011) used the integrated Biosphere Simulator (IBIS) to simulate GPP and $E_{\mathrm{a}}$ in China between 2002 and 2006. WUE was calculated as the ratio of GPP to evapotranspiration for different vegetation types. The study of Beer et al. (2009) used eddy covariance data to calculate both 


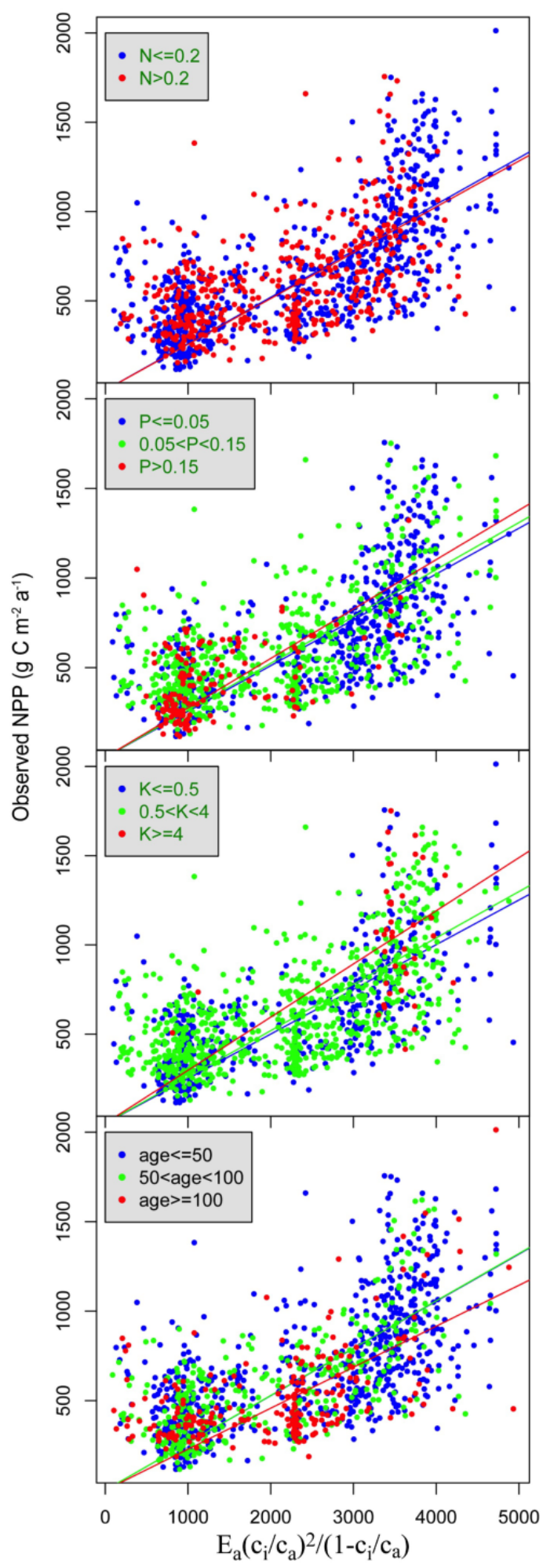

Fig. 3. Relationships between forest NPP and Level 1 WUE model predictors for different levels of soil nitrogen $(\mathrm{N})$, phosphorus $(\mathrm{P})$, potassium $(\mathrm{K})$ concentrations, and stand ages (years).
WUE and "inherent WUE" (the product of WUE and vapour pressure deficit) for different vegetation types. Our estimates of WUE were generally consistent with those of Zhu et al. (2011) but lower than those of Beer et al. (2009) (Fig. 6). This discrepancy is likely caused by the fact that data from rainy days, which would be characterized by high interception losses, were excluded from analysis by Beer et al. (2009). The close similarity of our fitted values for WUE for evergreen broadleaved, needle evergreen and mixed forests may arise because we assumed constant $c_{\mathrm{i}} / c_{\mathrm{a}}$ ratios for $\mathrm{MI} \geq 1$.

Knorr and Heimann (1995) obtained a global LUE for NPP of $\sim 0.02 \mathrm{~mol} \mathrm{C} \mathrm{mol}^{-1}$ photons based on their simple carbon cycle model, which was driven by fAPAR data and calibrated using observed seasonal cycles of atmospheric $\mathrm{CO}_{2}$ concentration at different latitudes. This is similar to our estimated value of $0.0293 \mathrm{~mol} \mathrm{C} \mathrm{mol}^{-1}$ photon, obtained from the regression slope of forest NPP on annual absorbed PAR in the Level 1 LUE model $\left(0.3516 \mathrm{~g} \mathrm{C} \mathrm{mol}^{-1}\right.$ photon: Table 1).

Our analyses provide no support for the hypotheses of Huston and Wolverton (2009). Huston and Wolverton hypothesized that forest NPP is lower in the tropics than in temperate regions. We find the opposite, i.e. for all models, there is a strong positive relationship between forest NPP and evapotranspiration or PAR - both variables that systematically increase from temperate towards tropical regions (Fig. 1). Huston and Wolverton also proposed that nutrient availability is the primary control on forest NPP. However, our results show that effects of nutrient availability - when considered over a large climatic range - are secondary to those of energy (whether expressed in terms of evapotranspiration or PAR) and water availability. This is clear from inspection of the relevant plots in Fig. 3, where the effects of nutrient status classes are dwarfed by the range of NPP values corresponding to the $\mathrm{x}$-axis predictors (which reflect the influence of energy and water in both models). Interestingly, the largest differences in regression slopes were for $\mathrm{K}$ rather than for $\mathrm{P}$ or $\mathrm{N}$, which are much more widely discussed as potential controls of productivity in ecological contexts.

The ratios of ANPP to total NPP for grassland were estimated to be $0.59(1-0.1442 / 0.3516)$ and 0.31 (1$0.1781 / 0.2589)$ by the Level 1 LUE and WUE models, respectively (Table 1). The former value is within while the latter value is below the range of 0.40 to 0.86 estimated by Hui and Jackson (2006) based on independent field data, with the lowest values applying to the driest sites. The grassland ANPP data come from a large range of vegetation types including typical steppe, meadow steppe, desert steppe and alpine grassland, so they encompass large differences in ANPP; and also very likely in the ANPP / NPP ratio, as they include sites ranging from wet to extremely dry climates. The available data are insufficient to support a more detailed analysis. So for the present, we can have less confidence in our models' applicability to non-forest vegetation types. 
WUEM
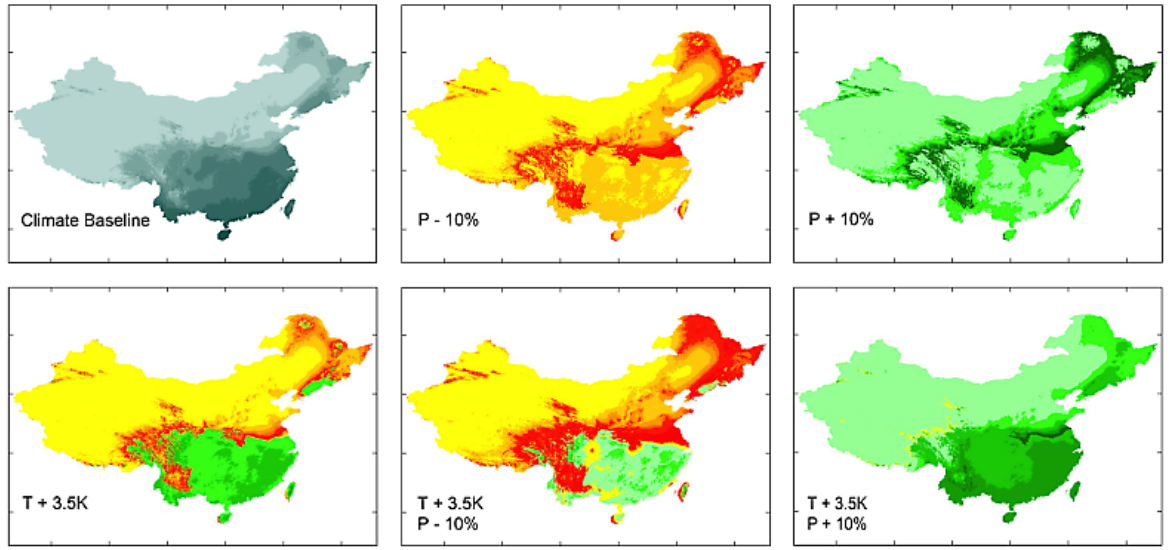

LUEM
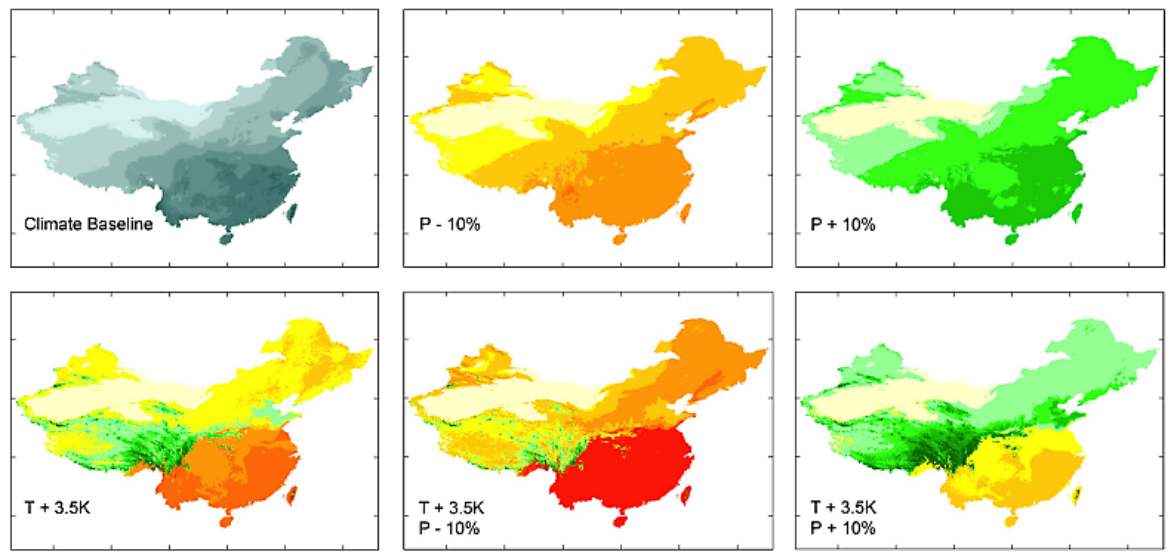

$\operatorname{NPP}\left(\mathrm{g} \mathrm{C} \mathrm{m}^{-2} \mathrm{a}^{-1}\right)$

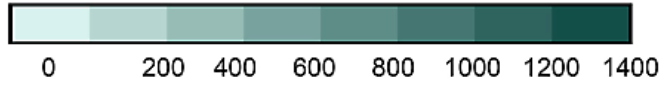

NPP Changes $\left(\mathrm{g} \mathrm{C} \mathrm{m}^{-2} \mathrm{a}^{-1}\right)$

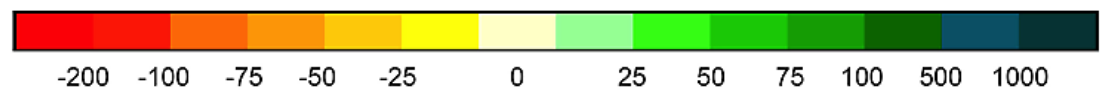

Fig. 4. The distribution pattern of NPP and NPP changes predicted by WUE model and LUE model, in six climatic scenarios under recent $\left[\mathrm{CO}_{2}\right]$.

\subsection{Contrasting effects of warming}

In the Level 1 WUE model warming induces higher equilibrium evapotranspiration and annual plant water use, which (if all else were equal) would imply greater $\mathrm{CO}_{2}$ uptake. However, warming also tends to increase drought, and therefore to increase the atmospheric vapour pressure deficit, resulting in stomatal closure, lower $c_{\mathrm{i}} / c_{\mathrm{a}}$ ratio and reduced $\mathrm{CO}_{2}$ uptake. The net effect of these two competing effects is to increase modelled NPP in humid South China while decreasing it in drier North China (Fig. 4).

In the Level 1 LUE model, warming reduces NPP through its effect on the $\mathrm{CO}_{2}$ compensation point, which is higher at high temperatures. Where warming also leads to drying, foliage cover and thus NPP are further reduced. On the other hand, since the driving variable IPAR $_{0}$ is defined as the total incident PAR integrated over the growing season, an extension of the growing season because of warming will allow more PAR to be used for photosynthesis; thus increasing NPP. In South China, where daily temperature is all above zero all year around, there can be no further extension of the growing season and therefore no positive effect on production through $\mathrm{IPAR}_{0}$; but there will still be a small negative effect of warming, due to the higher $\mathrm{CO}_{2}$ compensation point. As a result, warming has only negative effects on NPP in South China, according to this model. By contrast, 
WUEM
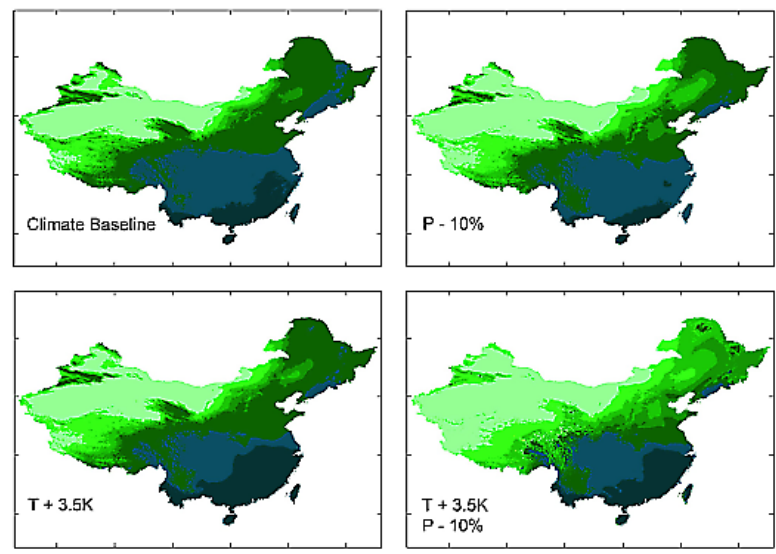

LUEM
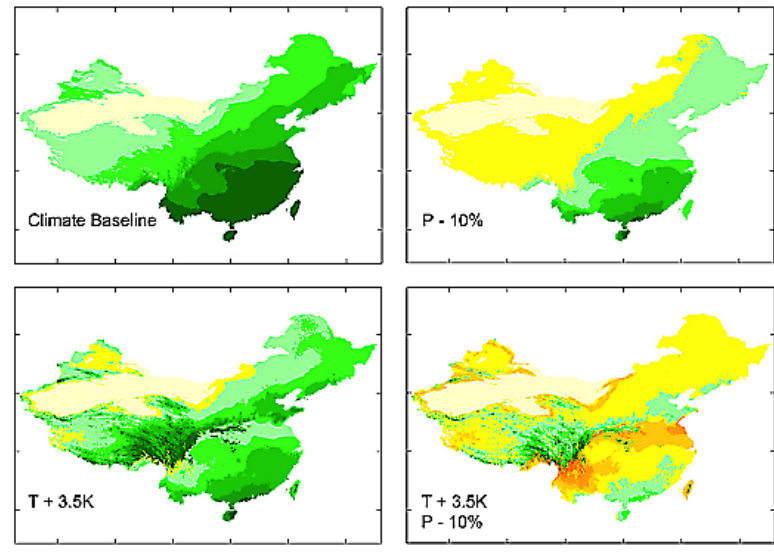

NPP Changes $\left(\mathrm{g} \mathrm{C} \mathrm{m}^{-2} \mathrm{a}^{-1}\right)$
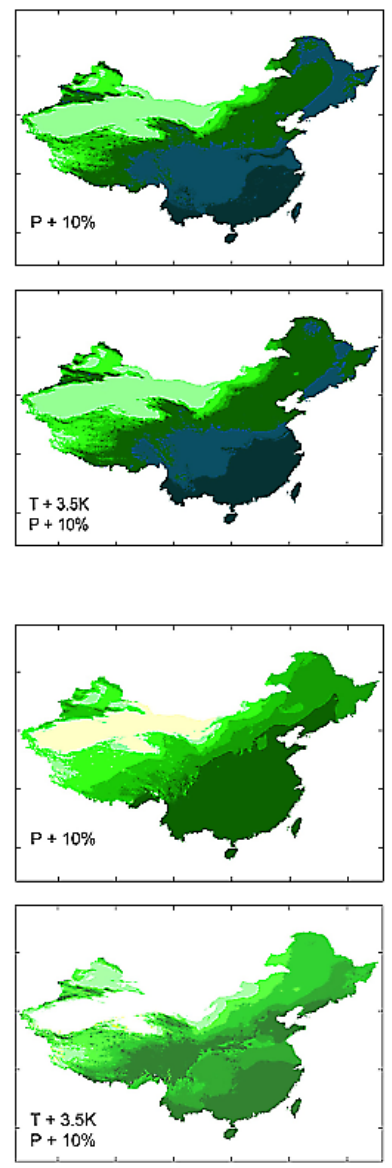

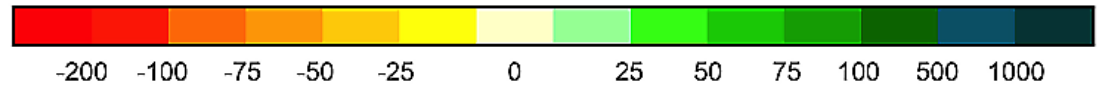

Fig. 5. The distribution pattern of NPP changes predicted by WUE model and LUE model, in six climatic scenarios under doubled $\left[\mathrm{CO}_{2}\right]$.

in colder North China, warming will lead to an extension of the growing season, and this positive effect on production can easily outweigh other effects. Especially on the Tibetan Plateau, which is a high-radiation environment with a short growing season, extension of the growing season leads to an especially strong positive effect due to the large effect of increasing $\mathrm{IPAR}_{0}$ (Fig. 4).

The modelled responses of NPP to mean annual temperature and precipitation are represented as response surfaces in Fig. 7. Even though both WUE and LUE models suggest the existence of an optimal temperature for NPP, this optimal temperature is affected differently by precipitation in the two models. In the WUE model, increased precipitation strongly shifts the optimal temperature to a higher value. In the LUE model the optimal temperature is more conservative, and modelled NPP declines with temperature above the optimum even under the warm and wet conditions found in southeastern China.

\subsection{Modelled effects of $\left[\mathrm{CO}_{2}\right]$ increase}

In the Level 1 WUE model, NPP responds to elevated $\left[\mathrm{CO}_{2}\right]$ on the assumption that actual evapotranspiration $E_{\mathrm{a}}$ is independent of $\left[\mathrm{CO}_{2}\right]$. However, because stomatal conductance $g_{\mathrm{s}}$ declines with increasing $\left[\mathrm{CO}_{2}\right]$ (Ainsworth and Rogers, 2007), then $E_{\mathrm{a}}$ can only be independent of $\left[\mathrm{CO}_{2}\right]$ in reality if foliage cover increases to fully compensate for any decline in $g_{\mathrm{s}}$. This might possibly be realistic for sparse vegetation, but it is very unlikely to be true for forests, where foliage is already absorbing a large proportion of the incident PAR. So the WUE model is expected to provide an upper bound for the effect of $\left[\mathrm{CO}_{2}\right]$ on productivity.

On the other hand, in the Level 1 LUE model, foliage cover is explicitly assumed not to adjust to the change in $\left[\mathrm{CO}_{2}\right]$ as a constant relationship between fAPAR and MI is assumed to hold. This is probably unrealistic for sparse vegetation, but it may be a reasonable approximation for forests. Thus, this 


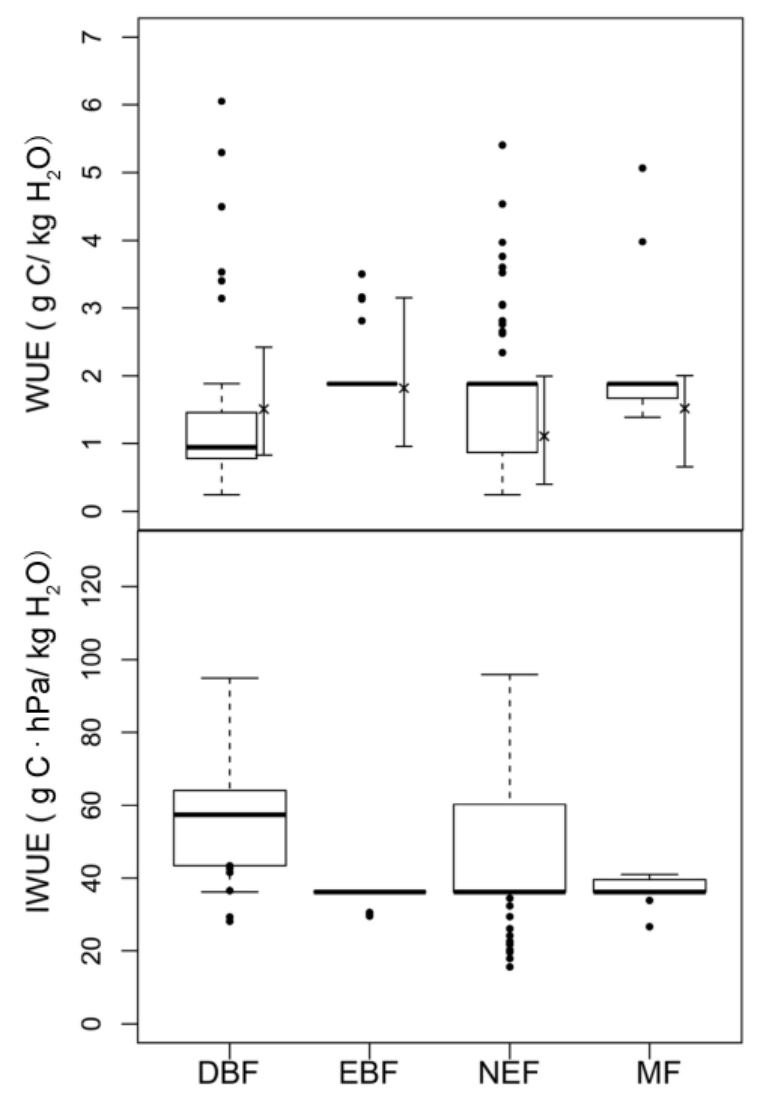

Fig. 6. Boxplot of water use efficiency (WUE) and inherent water use efficiency (IWUE) predicted by the Level 0 WUE model for four forest types: broad-leaved deciduous (DBF), broad-leaved evergreen forest (EBF), needle-leaved evergreen forest (NEF), mixed forest (MF), compared with the results from Beer et al. (2009), indicated by scatter points, and from Zhu et al. (2011), indicated by the line segment (range) with a cross symbol (mean value).

application of the LUE model will yield a lower bound for the $\mathrm{CO}_{2}$ effect (in so far as the $\mathrm{CO}_{2}$ response is not additionally constrained by other factors, such as nutrient availability), and may be reasonably realistic for forests.

The response surfaces (Fig. 7) imply that the effect of $\left[\mathrm{CO}_{2}\right]$ elevation in the models does not greatly modify the pattern of NPP response to climate, but does affect the sensitivity of NPP to climate.

\subsection{Caveats}

Both models have been implemented in a very simple way, probably leading to unrealistically abrupt spatial changes of sign in the responses of NPP to temperature and $\left[\mathrm{CO}_{2}\right]$. In the WUE model, the abrupt change in the temperature response occurs because the assumed values of the $c_{\mathrm{i}} / c_{\mathrm{a}}$ ratio have an imposed discontinuity at $\mathrm{MI}=1$, so that when MI > 1 warming-induced increases in vapour pressure deficit no longer reduce productivity. In the LUE model, the abrupt

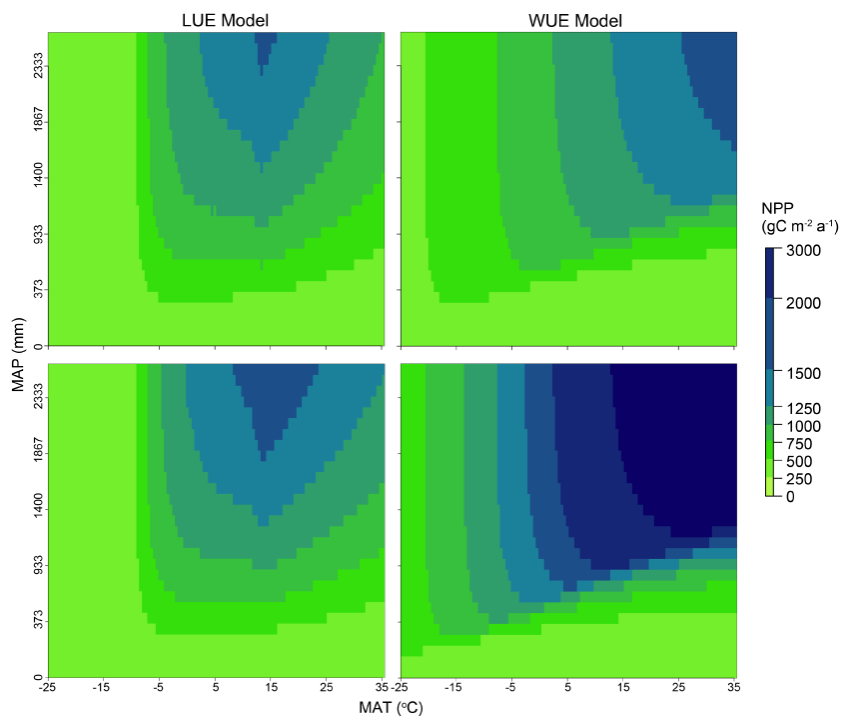

Fig. 7. Annual NPP responses to mean annual temperature (MAT) and mean annual precipitation (MAP) predicted by the LUE and WUE models under recent (upper panel) and doubled (lower panel) [CO2]. Seasonal cycles of monthly values corresponding to each value of MAT were obtained by adding a constant to the mean seasonal cycle across all the NPP mensuration plots. Monthly values corresponding to each value of MAP were obtained by multiplying the mean seasonal cycle by a constant. These conventions provide a reasonable approximation to the range of climatic conditions found in China.

change in the temperature response occurs because of the discontinuity in $\mathrm{IPAR}_{0}$ when all days are included in the growing season. The calculation ignores variability within the colder months; if included, this variability would probably induce a smoother transition between temperature-limited and unlimited growing seasons lengths and would allow the growing-season length to continue increasing even when the mean temperature of the coldest month is greater than $0{ }^{\circ} \mathrm{C}$.

Nevertheless, the simple formulations adopted here seem qualitatively reasonable. The discontinuities in both models' responses occur along the natural boundary between the warm-temperate (predominantly evergreen) forests of South China and the temperate (deciduous and mixed) forests of North China. The $c_{\mathrm{i}} / c_{\mathrm{a}}$ ratio is likely to be well below 1 , as it can only be equal to 1 in the absence of net photosynthesis. Some cut-off or asymptote in the response of $c_{\mathrm{i}} / c_{\mathrm{a}}$ to water availability is therefore inescapable. It is also undeniable that in sufficiently warm climates, with evergreen vegetation, further warming will no longer add to growing season length and therefore to utilized PAR. Thus, even if more realistic formulations allowed for smooth transitions between regimes, there would still be two regimes for each model and the sign of the responses of the two models would still be opposite in the warm, wet region of South China and in the colder, drier regions to the north and west. 


\subsection{Implications for modelling}

Our analysis of the qualitative discrepancy between two alternative simple model formulations highlights the importance of the response of vegetation cover to $\left[\mathrm{CO}_{2}\right]$, which is not well studied. The results have implications not only for the effect of $\left[\mathrm{CO}_{2}\right]$ on NPP but also for the (controversial) possible positive effect of $\left[\mathrm{CO}_{2}\right]$ on freshwater runoff (Gedney et al., 2006). The reason is simply that if vegetation cover increases to compensate for reduced $g_{\mathrm{s}}$, as is implicitly assumed by the WUE model, then there will be no increase in runoff. On the other hand if vegetation cover does not increase in response to $\left[\mathrm{CO}_{2}\right]$, as is explicitly assumed by the LUE model, then reduced $g_{\mathrm{s}}$ would be expected to lead to an increase in runoff. Thus, the contrast between the two models highlights the fact that effects of $\left[\mathrm{CO}_{2}\right]$ in increasing foliage cover and increasing runoff are complementary. The WUE model represents one extreme case, in which foliage cover is allowed to increase as required to increase NPP in proportion to $\left[\mathrm{CO}_{2}\right]$. The LUE model represents the opposite case in which foliage cover maintains a fixed relationship with MI irrespective of $\left[\mathrm{CO}_{2}\right]$.

Even though this first-principles analysis illustrates a potential cause of the differences (even in sign) in the global NPP response of dynamic global vegetation models to $\left[\mathrm{CO}_{2}\right]$ and climate change (Denman et al., 2007), there is no clear evidence for which response is more realistic in all vegetation types, or how some compromise between these models should be formulated. We therefore conclude that it is important for observational and experimental studies to explicitly address the two key differences in the model predictions of $\left[\mathrm{CO}_{2}\right]$ response, i.e. the extent to which vegetation cover in different ecosystems increases (or not) and the extent to which water use decreases (or not), and the sign and magnitude of the NPP response to warming in the warmer and colder regions.

\subsection{Implications for global change impacts on NPP in China}

Some tentative conclusions can be drawn about the response of NPP of China's ecosystems to global environmental change. Some positive effect of increasing $\left[\mathrm{CO}_{2}\right]$ is to be expected generally. The effect on NPP is likely to be greater in semi-arid regions where foliage cover can increase, whereas the effect on runoff is likely to be greater in wetter regions. The effect of precipitation changes will depend directly on the sign of those changes, which may well be opposite in different regions (Meehl et al., 2007). The response to warming however remains unresolved.
Acknowledgements. This work was supported by a National Basic Research Program of China grant (2010CB951303) and an award to J. N. from the One Hundred Talents Program of the Chinese Academy of Sciences. We thank the China Scholarship Council (CSC) and Macquarie University for supporting H. W. to study at Macquarie. We also thank C. Beer and M. Reichstein for providing their global GPP product.

Edited by: U. Seibt

\section{References}

Ainsworth, E. A. and Rogers, A.: The response of photosynthesis and stomatal conductance to rising $\left[\mathrm{CO}_{2}\right]$ : mechanisms and environmental interactions, Plant Cell Environ., 30, 258-270, doi:10.1111/j.1365-3040.2007.01641.x, 2007.

Baldocchi, D.: A comparative study of mass and energy exchange rates over a closed $\mathrm{C}_{3}$ (wheat) and an open $\mathrm{C}_{4}$ (corn) crop: II. $\mathrm{CO}_{2}$ exchange and water use efficiency, Agr. Forest Meteorol., 67, 291-321, doi:10.1016/0168-1923(94)90008-6, 1994.

Beer, C., Reichstein, M., Ciais, P., Farquhar, G. D., and Papale, D.: Mean annual GPP of Europe derived from its water balance, Geophys. Res. Lett., 34, L05401, doi:10.1029/2006g1029006, 2007.

Beer, C., Ciais, P., Reichstein, M., Baldocchi, D., Law, B. E., Papale, D., Soussana, J. F., Ammann, C., Buchmann, N., Frank, D., Gianelle, D., Janssens, I. A., Knohl, A., Koestner, B., Moors, E., Roupsard, O., Verbeeck, H., Vesala, T., Williams, C. A., and Wohlfahrt, G.: Temporal and among-site variability of inherent water use efficiency at the ecosystem level, Global Biogeochem. Cy., 23, Gb2018, doi:10.1029/2008gb003233, 2009.

Beer, C., Reichstein, M., Tomelleri, E., Ciais, P., Jung, M., Carvalhais, N., Rödenbeck, C., Arain, M. A., Baldocchi, D., Bonan, G. B., Bondeau, A., Cescatti, A., Lasslop, G., Lindroth, A., Lomas, M., Luyssaert, S., Margolis, H., Oleson, K. W., Roupsard, O., Veenendaal, E., Viovy, N., Williams, C., Woodward, F. I., and Papale, D.: Terrestrial Gross Carbon Dioxide Uptake: Global Distribution and Covariation with Climate, Science, 329, 834-838, doi:10.1126/science.1184984, 2010.

Bernacchi, C. J., Pimentel, C., and Long, S. P.: In vivo temperature response functions of parameters required to model RuBP-limited photosynthesis, Plant Cell Environ., 26, 14191430, doi:10.1046/j.0016-8025.2003.01050.x, 2003.

Challinor, A. J., Wheeler, T. R., Craufurd, P. Q., Slingo, J. M., and Grimes, D. I. F.: Design and optimisation of a large-area processbased model for annual crops, Agr. Forest Meteorol., 124, 99120, doi:10.1016/j.agrformet.2004.01.002, 2004.

Christensen, J. H., Hewitson, B., Busuioc, A., Chen, A., Gao, X., Held, I., Jones, R., Kolli, R. K., Kwon, W.-T., Laprise, R., Magaña Rueda, V., Mearns, L., Menéndez, C. G., Räisänen, J., Rinke, A., Sarr, A., and Whetton, P.: Regional Climate Projections, in: Climate Change 2007: The Physical Science Basis. Contribution of Working Group I to the Fourth Assessment Report of the Intergovernmental Panel on Climate Change, edited by: Solomon, S., Qin, D., Manning, M., Chen, Z., Marquis, M., Averyt, K. B., Tignor, M., and Miller, H. L., Cambridge University Press, Cambridge, United Kingdom and New York, NY, USA, 2007.

Cramer, W., Bondeau, A., Woodward, F. I., Prentice, I. C., Betts, R. A., Brovkin, V., Cox, P. M., Fisher, V., Foley, J. A., Friend, 
A. D., Kucharik, C., Lomas, M. R., Ramankutty, N., Sitch, S., Smith, B., White, A., and Young-Molling, C.: Global response of terrestrial ecosystem structure and function to $\mathrm{CO}_{2}$ and climate change: results from six dynamic global vegetation models, Glob. Change Biol., 7, 357-373, doi:10.1046/j.13652486.2001.00383.x, 2001.

DeLucia, E. H., Drake, J. E., Thomas, R. B., and Gonzalez-Meler, M.: Forest carbon use efficiency: is respiration a constant fraction of gross primary production?, Glob. Change Biol., 13, 11571167, doi:10.1111/j.1365-2486.2007.01365.x, 2007.

Denman, K. L., Brasseur, G., Chidthaisong, A., Ciacis, P., Cox, P. M., Hauglustaine, D., Heinze, C., Holland, E., Jacob, D., Lohmann, U., Ramachandran, S., Da Silva Dias, P. L., Wofsy, S. C., and Zhang, X.: Couplings Between Changes in the Climate System and Biogeochemistry, in: Climate Change 2007: The Physical Science Basis, Contribution of Working Group I to the Fourth Assessment Report of the Intergovernmental Panel on Climate Change, edited by: Solomon, S., Qin, D., Manning, M., Chen, Z., Marquis, M., Averyt, K. B., Tignor, M., and Miller, H. L., Cambridge University Press, Cambridge, United Kingdom and New York, NY, USA, 499-587, 2007.

Dewar, R. C.: The Correlation between Plant Growth and Intercepted Radiation: An Interpretation in Terms of Optimal Plant Nitrogen Content, Ann. Bot.-London, 78, 125-136, doi:10.1006/anbo.1996.0104, 1996.

Farquhar, G. D., Caemmerer, S., and Berry, J. A.: A biochemical model of photosynthetic $\mathrm{CO}_{2}$ assimilation in leaves of $\mathrm{C}_{3}$ species, Planta, 149, 78-90, doi:10.1007/bf00386231, 1980.

Farquhar, G. D., O'Leary, M., and Berry, J.: On the Relationship Between Carbon Isotope Discrimination and the Intercellular Carbon Dioxide Concentration in Leaves, Funct. Plant Biol., 9, 121137, doi:10.1071/PP9820121, 1982.

Farquhar, G. D., Ehleringer, J. R., and Hubick, K. T.: Carbon Isotope Discrimination and Photosynthesis, Annu. Rev. Plant Phys., 40, 503-537, doi:10.1146/annurev.pp.40.060189.002443, 1989.

Friedlingstein, P. and Prentice, I. C.: Carbon-climate feedbacks: a review of model and observation based estimates, Curr. Opin. Environ. Sustainability, 2, 251-257, doi:10.1016/j.cosust.2010.06.002, 2010.

Friedlingstein, P., Cox, P., Betts, R., Bopp, L., von Bloh, W., Brovkin, V., Cadule, P., Doney, S., Eby, M., Fung, I., Bala, G., John, J., Jones, C., Joos, F., Kato, T., Kawamiya, M., Knorr, W., Lindsay, K., Matthews, H. D., Raddatz, T., Rayner, P., Reick, C., Roeckner, E., Schnitzler, K. G., Schnur, R., Strassmann, K., Weaver, A. J., Yoshikawa, C., and Zeng, N.: Climate-Carbon Cycle Feedback Analysis: Results from the C4MIP Model Intercomparison, J. Climate, 19, 3337-3353, doi:10.1175/jcli3800.1, 2006

Gedney, N., Cox, P. M., Betts, R. A., Boucher, O., Huntingford, C., and Stott, P. A.: Detection of a direct carbon dioxide effect in continental river runoff records, Nature, 439, 835-838, 2006.

Gobron, N., Pinty, B., Aussedat, O., Chen, J. M., Cohen, W. B., Fensholt, R., Gond, V., Huemmrich, K. F., Lavergne, T., Melin, F., Privette, J. L., Sandholt, I., Taberner, M., Turner, D. P., Verstraete, M. M., and Widlowski, J.-L.: Evaluation of fraction of absorbed photosynthetically active radiation products for different canopy radiation transfer regimes: Methodology and results using Joint Research Center products derived from SeaWiFS against ground-based estimations, J. Geophys. Res.-Atmos., 111,
D13110, doi:10.1029/2005jd006511, 2006.

Hancock, P. A. and Hutchinson, M. F.: Spatial interpolation of large climate data sets using bivariate thin plate smoothing splines, Environ. Modell. Softw., 21, 1684-1694, doi:10.1016/j.envsoft.2005.08.005, 2006.

Haxeltine, A. and Prentice, I. C.: A general model for the lightuse efficiency of primary production, Funct. Ecol., 10, 551-561, doi:10.2307/2390165, 1996a.

Haxeltine, A. and Prentice, I. C.: BIOME3: An equilibrium terrestrial biosphere model based on ecophysiological constraints, resource availability, and competition among plant functional types, Global Biogeochem. Cycles, 10, 693-709, doi:10.1029/96gb02344, 1996b.

Hui, D. F. and Jackson, R. B.: Geographical and interannual variability in biomass partitioning in grassland ecosystems: a synthesis of field data, New Phytol., 169, 85-93, doi:10.1111/j.14698137.2005.01569.x, 2006.

Huston, M. A. and Wolverton, S.: The global distribution of net primary production: resolving the paradox, Ecol. Monogr., 79, 343-377, doi:10.1890/08-0588.1, 2009.

Jassal, R. S., Black, T. A., Spittlehouse, D. L., Brümmer, C., and Nesic, Z.: Evapotranspiration and water use efficiency in different-aged Pacific Northwest Douglasfir stands, Agr. Forest Meteorol., 149, 1168-1178, doi:10.1016/j.agrformet.2009.02.004, 2009.

Kergoat, L.: A model for hydrological equilibrium of leaf area index on a global scale, J. Hydrol., 212, 268-286, 10.1016/s00221694(98)00211-x, 1998.

Kuglitsch, F. G., Reichstein, M., Beer, C., Carrara, A., Ceulemans, R., Granier, A., Janssens, I. A., Koestner, B., Lindroth, A., Loustau, D., Matteucci, G., Montagnani, L., Moors, E. J., Papale, D., Pilegaard, K., Rambal, S., Rebmann, C., Schulze, E. D., Seufert, G., Verbeeck, H., Vesala, T., Aubinet, M., Bernhofer, C., Foken, T., Grünwald, T., Heinesch, B., Kutsch, W., Laurila, T., Longdoz, B., Miglietta, F., Sanz, M. J., and Valentini, R.: Characterisation of ecosystem water-use efficiency of european forests from eddy covariance measurements, Biogeosciences Discuss. 5, 4481-4519, doi:10.5194/bgd-5-4481-2008, 2008.

Knorr, W. and Heimann, M.: Impact of drought stress and other factors on seasonal land biosphere $\mathrm{CO}_{2}$ exchange studied through an atmospheric tracer transport model, Tellus, 47, 471-489, 1995.

Luo, Y.: Patterns of net primary productivity for Chinese major forest types and their mathematical models, Doctor of Philosophy, Chinese Academy of Sciences, 1996.

Luyssaert, S., Inglima, I., Jung, M., Richardson, A. D., Reichstein, M., Papale, D., Piao, S. L., Schulze, E. D., Wingate, L., Matteucci, G., Aragao, L., Aubinet, M., Beer, C., Bernhofer, C., Black, K. G., Bonal, D., Bonnefond, J. M., Chambers, J., Ciais, P., Cook, B., Davis, K. J., Dolman, A. J., Gielen, B., Goulden, M., Grace, J., Granier, A., Grelle, A., Griffis, T., GrÜNwald, T., Guidolotti, G., Hanson, P. J., Harding, R., Hollinger, D. Y., Hutyra, L. R., Kolari, P., Kruijt, B., Kutsch, W., Lagergren, F., Laurila, T., Law, B. E., Le Maire, G., Lindroth, A., Loustau, D., Malhi, Y., Mateus, J., Migliavacca, M., Misson, L., Montagnani, L., Moncrieff, J., Moors, E., Munger, J. W., Nikinmaa, E., Ollinger, S. V., Pita, G., Rebmann, C., Roupsard, O., Saigusa, N., Sanz, M. J., Seufert, G., Sierra, C., Smith, M. L., Tang, J., Valentini, R., Vesala, T., and Janssens, I. A.: 
$\mathrm{CO}_{2}$ balance of boreal, temperate, and tropical forests derived from a global database, Glob. Change Biol., 13, 2509-2537, doi:10.1111/j.1365-2486.2007.01439.x, 2007.

Makela, A. and Valentine, H. T.: The ratio of NPP to GPP: evidence of change over the course of stand development, Tree Physiol., 21, 1015-1030, 2001.

Manzoni, S., Katul, G., Fay, P. A., Polley, H. W., and Porporato, A.: Modeling the vegetation-atmosphere carbon dioxide and water vapor interactions along a controlled $\mathrm{CO}_{2}$ gradient, Ecol. Model., 222, 653-665, doi:10.1016/j.ecolmodel.2010.10.016, 2011.

Medlyn, B. E., Duursma, R. A., Eamus, D., Ellsworth, D. S., Prentice, I. C., Barton, C. V. M., Crous, K. Y., De Angelis, P., Freeman, M., and Wingate, L.: Reconciling the optimal and empirical approaches to modelling stomatal conductance, Glob. Change Biol., 17, 2134-2144, doi:10.1111/j.1365-2486.2010.02375.x, 2011.

Meehl, G. A., Stocker, T. F., Collins, W. D., Friedlingstein, P., Gaye, A. T., Gregory, J. M., Kitoh, A., Knutti, R., Murphy, J. M., Noda, A., Raper, S. C. B., Watterson, I. G., Weaver, A. J., and Zhao, Z.-C.: Global Climate Projections, in: Climate Change 2007: The Physical Science Basis. Contribution of Working Group I to the Fourth Assessment Report of the Intergovernmental Panel on Climate Change, edited by: Solomon, S., Qin, D., Manning, M., Chen, Z., Marquis, M., Averyt, K. B., Tignor, M., and Miller, H. L., Cambridge University Press, Cambridge, United Kingdom and New York, NY, USA, 2007.

Monteith, J. L. and Moss, C. J.: Climate and the Efficiency of Crop Production in Britain [and Discussion], Philos. T. Roy. Soc. B, 281, 277-294, doi:10.1098/rstb.1977.0140, 1977.

Nemani, R. R. and Running, S. W.: Testing a theoretical climatesoil-leaf area hydrologic equilibrium of forests using satellite data and ecosystem simulation, Agr. Forest Meteorol., 44, 245260, 10.1016/0168-1923(89)90020-8, 1989.

$\mathrm{Ni}, \mathrm{J}$. : Net primary productivity in forests of China: scaling-up of national inventory data and comparison with model predictions, Forest Ecol. Manag., 176, 485-495, doi:10.1016/s03781127(02)00312-2, 2003.

$\mathrm{Ni}$, J.: Estimating net primary productivity of grasslands from field biomass measurements in temperate northern China, Plant Ecol., 174, 217-234, doi:10.1023/b:vege.0000049097.85960.10, 2004.

Piao, S., Luyssaert, S., Ciais, P., Janssens, I. A., Chen, A., Cao, C., Fang, J., Friedlingstein, P., Luo, Y., and Wang, S.: Forest annual carbon cost: a global-scale analysis of autotrophic respiration, Ecology, 91, 652-661, doi:10.1890/08-2176.1, 2010.

Prentice, I. C., Sykes, M. T., and Cramer, W.: A simulation-model for the transient effects of climate change on forest landscapes, Ecol. Model., 65, 51-70, 1993.

Prentice, I. C., Farquhar, G. D., Fasham, M. J. R., Goulden, M. L., Heimann, M., Jaramillo, V. J., Kheshgi, H. S., Le Quéré, C., Scholes, R. J., and Wallace, D. W. R.: The carbon cycle and atmospheric carbon dioxide, in: Climate Change 2001: The Scientific Basis. Contribution of Working Group I to the Third Assessment Report of the Intergovernmental Panel on Climate Change, edited by: Houghton, J. T., Ding, Y., Griggs, D. J., Noguer, M., van der Linden, P. J., Dai, X., Maskell, K., and Johnson, C. A., Cambridge University Press, Cambridge, United Kingdom and New York, NY, USA, 183-237, 2001.

Prentice, I. C., Meng, T., Wang, H., Harrison, S. P., Ni, J., and Wang, G.: Evidence of a universal scaling relationship for leaf $\mathrm{CO}_{2}$ drawdown along an aridity gradient, New Phytol., 190, 169-180, doi:10.1111/j.1469-8137.2010.03579.x, 2011.

Prince, S. D. and Goward, S. N.: Global primary production: A remote sensing approach, J. Biogeogr., 22, 815-835, doi:10.2307/2845983, 1995.

Raupach, M. R.: Vegetation-atmosphere interaction in homogeneous and heterogeneous terrain some implications of mixed-layer dynamics, Vegetation, 91, 105-120, doi:10.1007/bf00036051, 1991.

Running, S. W., Nemani, R. R., Heinsch, F. A., Zhao, M. S., Reeves, M., and Hashimoto, H.: A continuous satellite-derived measure of global terrestrial primary production, Bioscience, 54, 547560, 2004.

Shi, X. Z., Yu, D. S., Warner, E. D., Pan, X. Z., Petersen, G. W., Gong, Z. G., and Weindorf, D. C.: Soil database of 1:1000 000 digital soil survey and reference system of the Chinese genetic soil classification system, Soil Survey Horizons, 45, 129-136, 2004.

Sitch, S., Smith, B., Prentice, I. C., Arneth, A., Bondeau, A., Cramer, W., Kaplan, J. O., Levis, S., Lucht, W., Sykes, M. T., Thonicke, K., and Venevsky, S.: Evaluation of ecosystem dynamics, plant geography and terrestrial carbon cycling in the LPJ dynamic global vegetation model, Glob. Change Biol., 9, 161-185, doi:10.1046/j.1365-2486.2003.00569.x, 2003.

Sitch, S., Huntingford, C., Gedney, N., Levy, P. E., Lomas, M., Piao, S. L., Betts, R., Ciais, P., Cox, P., Friedlingstein, P., Jones, C. D., Prentice, I. C., and Woodward, F. I.: Evaluation of the terrestrial carbon cycle, future plant geography and climate-carbon cycle feedbacks using five Dynamic Global Vegetation Models (DGVMs), Glob. Change Biol., 14, 2015-2039, doi:10.1111/j.1365-2486.2008.01626.x, 2008.

Sokolov, A. P., Kicklighter, D. W., Melillo, J. M., Felzer, B. S., Schlosser, C. A., and Cronin, T. W.: Consequences of Considering Carbon-Nitrogen Interactions on the Feedbacks between Climate and the Terrestrial Carbon Cycle, J. Climate, 21, 37763796, doi:10.1175/2008jcli2038.1, 2008.

Specht, R. L.: Water use by perennial evergreen plant communities in australia and papua new-guinea, Aust. J. Bot., 20, 273-299, doi:10.1071/bt9720273, 1972.

Thornton, P. E., Doney, S. C., Lindsay, K., Moore, J. K., Mahowald, N., Randerson, J. T., Fung, I., Lamarque, J.-F., Feddema, J. J., and Lee, Y.-H.: Carbon-nitrogen interactions regulate climate-carbon cycle feedbacks: results from an atmosphereocean general circulation model, Biogeosciences, 6, 2099-2120, doi:10.5194/bg-6-2099-2009, 2009.

Wang, H., Ni, J., and Prentice, I.: Sensitivity of potential natural vegetation in China to projected changes in temperature, precipitation and atmospheric $\mathrm{CO}_{2}$, Reg. Environ. Change, 11, 715727, doi:10.1007/s10113-011-0204-2, 2011.

Waring, R. H., Landsberg, J. J., and Williams, M.: Net primary production of forests: a constant fraction of gross primary production?, Tree Physiol., 18, 129-134, 1998.

Wong, S. C., Cowan, I. R., and Farquhar, G. D.: Stomatal conductance correlates with photosynthetic capacity, Nature, 282, 424 426, 1979.

Wullschleger, S. D.: Biochemical limitations to carbon assimilation in $\mathrm{c}(3)$ plants - a retrospective analysis of the a/ci curves from 109 species, J. Exp. Bot., 44, 907-920, doi:10.1093/jxb/44.5.907, 1993. 
Zaehle, S. and Friend, A. D.: Carbon and nitrogen cycle dynamics in the O-CN land surface model: 1. Model description, site-scale evaluation, and sensitivity to parameter estimates, Global Biogeochem. Cy., 24, GB1005, doi:10.1029/2009gb003521, 2010.

Zhang, L., Hickel, K., Dawes, W. R., Chiew, F. H. S., Western, A. W., and Briggs, P. R.: A rational function approach for estimating mean annual evapotranspiration, Water Resour. Res., 40, W02502, doi:10.1029/2003wr002710, 2004.

Zhang, Y. J., Xu, M., Chen, H., and Adams, J.: Global pattern of NPP to GPP ratio derived from MODIS data: effects of ecosystem type, geographical location and climate, Global Ecol. Biogeogr., 18, 280-290, doi:10.1111/j.1466-8238.2008.00442.x, 2009.
Zhou, S., Duursma, R., Medlyn, B., and Prentice, I. C.: How should we model plant responses to draught?: a meta-analysis of stomatal and non-stomatal response water stress (unpublished results), 2012.

Zhu, Q., Jiang, H., Peng, C., Liu, J., Wei, X., Fang, X., Liu, S., Zhou, G., and Yu, S.: Evaluating the effects of future climate change and elevated $\mathrm{CO}_{2}$ on the water use efficiency in terrestrial ecosystems of China, Ecol. Model., 222, 2414-2429, doi:10.1016/j.ecolmodel.2010.09.035, 2011. 